\title{
Effect of different combination levels of palm kernel cake, yam peel and plantain peel meals as partial replacement for maize in broiler starter diets.
}

E. B. *Etuk, B. Anopueme, I. F. Etuk, J. S. Ekpo, O. O. Emenalom and B. O. Esonu

Department of Animal Science and Technology

Federal University of Technology, PMB. 1526, Owerri, Nigeria.

*Author for correspondence: edeheetuk@yahoo.com

\begin{abstract}
Ninety six unsexed day old Marshall broiler chickens were divided into 4 groups of 3 replicates each on weight equalization basis $(42.87-43.24 \mathrm{~g})$. The chicks were used to determine the effect of partial replacement of maize with combinations of palm kernel cake (PKC), yam peel meal (YPM) and plantain peel meal (PPM) in broiler starter diets. Four broiler starter diets were formulated such that diet T1 (control) contained 54\% maize. Diets T2, T3 and T4 contained PKC, YPM and PPM in the ratios, 1:1:2, 1: 2:1 and 1: 1: 2 replacing 50\% of maize. The chick groups were each randomly assigned to one of the experimental broiler starter diets in a completely randomised design (CRD) experiment. The feed and water were offered ad libitum. Results indicated that birds on diet T4 recorded significantly $(p<0.05)$ higher (861.63g) body weight gain than those on other diets. Feed intake followed similar trend with birds on diet $T 1$ recording significantly $(p<0.05)$ lower $(1564.63 g)$ value than other groups. Feed conversion ratio was comparable $(p>0.05)$ for all groups while feed cost savings relative to the control diet ranged from $23.51-24.51 \%$. Birds on diets $T 4$ recorded the lowest feed cost per $\mathrm{kg}$ body weight gain. It is concluded that combinations of PKC, YPM and PPM could safely replace 50\% of maize in broiler starter diet with 1:1:2 combination ratio producing a superior performance.
\end{abstract}

Key Words: Combinations, Palm kernel cake, Yam peel, Plantain peel, Broilers

\section{Introduction}

Maize, which is the predominantly used ingredient for energy in poultry feed in Nigeria, is very costly now because of higher demand for it by humans as food in various forms, and industrial purposes. Alternatives should, therefore, be sourced especially from materials that are not used as food by man, and of less or no industrial value. These materials should be relatively rich sources of energy in order to adequately replace maize in poultry feed. Of particular interest currently are domestic wastes and agro-industrial by-products including cassava peel, yam peel, plantain peel (Nworgu and Ogbosuka, 2003; Akinmutimi et al., 2006) palm kernel cake (Ezieshi et al, 2004) and other nonconventional feeding stuffs (Akanno, 1998.)

Metabolizable energy and crude protein contents of yam peel has been reported to be $2604 \mathrm{Kcal} / \mathrm{kg}$ and $11 \%$, respectively (Eka, 1998; Akanno, 1998). Yam peel is not expensive compared to maize (Akinmutimi et al., 2006), its use as animal feed will help to reduce waste disposal problems; and also 
help to promote clean, healthy and safe environment. The other advantage of utilizing domestic wastes and agroindustrial wastes may be that of creating wealth from wastes for people who are involved in the processing of these materials into useful forms. This study was therefore; design to assess different combinations of palm kernel cake, yam peel meal (YPM) and plantain peel meal (PPM) as partial replacement of maize in broiler starter diets.

\section{Materials and Methods}

Yam peels and plantain peels were procured from restaurants within the Federal University of Technology, Owerri, Nigeria.
The peels were sun dried until they became crispy to touch, separately hammer milled via a $2 \mathrm{~mm}$ sieve to produce yam peel meal (YPM) and plantain peel meal (PPM). The hydraulic pressed palm kernel cake was procured from Fidelity Agro Services in Owerri. These test materials were analysed for gross energy and proximate composition using standard methods (AOAC, 1995).

Four experimental broiler starter diets were formulated such that diet T1 (control) contained only maize as the major energy source. Diets T2, T3 and T5 contained PKC, YPM and PPM combined respectively, in the ratio; $2: 1: 1,1: 2: 1$ and $1: 1: 2$. (Table 1 ). Ninety six, day old Marshall broilers were

Table 1: Gross composition of experimental broiler starter diets

\begin{tabular}{|c|c|c|c|c|}
\hline \multirow{2}{*}{ Ingredients } & \multicolumn{4}{|c|}{ Combination ratios of $\mathrm{PKC}, \mathrm{YPM}$ and PPM } \\
\hline & T1(0:0:0) & T2(2:1:1) & T3(1:2:1) & T4(1:1:2) \\
\hline Maize & 54.00 & 27.00 & 27.00 & 27.00 \\
\hline Soybean meal & 26.00 & 26.00 & 26.00 & 26.00 \\
\hline Palm kernel cake & 0.00 & 13.50 & 6.75 & 6.75 \\
\hline Yam peel & 0.00 & 6.75 & 13.50 & 6.75 \\
\hline Plantain peel & 0.00 & 6.75 & 6.75 & 6.75 \\
\hline Wheat offal & 8.00 & 8.00 & 8.00 & 8.00 \\
\hline Fish meal & 5.00 & 5.00 & 5.00 & 5.00 \\
\hline Blood meal & 3.00 & 3.00 & 3.00 & 3.00 \\
\hline Bone meal & 3.00 & 3.00 & 3.00 & 3.00 \\
\hline Vitamin /mineral premix* & 0.25 & 0.25 & 0.25 & 0.25 \\
\hline L- methionine & 0.25 & 0.25 & 0.25 & 0.25 \\
\hline L- lysine & 0.25 & 0.25 & 0.25 & 0.25 \\
\hline Salt & 0.25 & 0.25 & 0.25 & 0.25 \\
\hline Total & 100.00 & 100.00 & 100.00 & 100.00 \\
\hline \multicolumn{5}{|c|}{ Calculated nutrient composition of experimental broiler starter diet $(\%)$} \\
\hline Metabolisable Energy $(\mathrm{Kcal} / \mathrm{Kg})$ & 2800.00 & 2598.79 & 2566.85 & 2597.50 \\
\hline Crude protein & 23.00 & 23.82 & 23.88 & 24.42 \\
\hline Ether extract & 3.88 & 5.60 & 3.99 & 4.42 \\
\hline Crude fibre & 4.10 & 7.30 & 7.52 & 7.60 \\
\hline Calcium & 1.26 & 1.27 & 1.27 & 1.30 \\
\hline Phosphorus & 0.52 & 0.99 & 0.99 & 1.05 \\
\hline \multicolumn{5}{|c|}{$\begin{array}{l}\text { * Hi Nutrient International broiler starter premix providing the following per 25kg; Vitamin A, } \\
\text { 8,000,000iu; Vitamin D3, 16,000,000iu, Vitamin E, 20,000mg, Vitamin K, 2000mg; Vitamin B , } \\
\text { 1,500mg; Vitamin B2, 4,000mg; Vitamin B6, 2,000mg; Vitamin B 12, 10mg; Niacin, 15,000mg; } \\
\text { Panthothenic acid, 5000mg; Folic acid, 500mg; Biotin, 20mg; Choline chloride, 200,000mg; Manganese, } \\
\text { 80,000mg; Zinc, 50,000mg; iron, 20,000mg; Copper, 5,000mg; Iodine, 1,000mg; Selenium, 200mg; } \\
\text { Cobalt, 500mg, Anti oxidant, 120,000mg. }\end{array}$} \\
\hline
\end{tabular}


divided into four groups of 24 chicks each on weight equalization basis. Each group was randomly assigned to one of the diets in a completely randomised design (CRD) experimental arrangement. Each treatment group was replicated three times and raised on deep litter in an open sided poultry house. Feed and water were offered ad libitum. Medications, vaccinations and other routine management practices were strictly followed. The feeding trial lasted 28 days.

Chicks were weighed at the beginning of the experiment and on weekly basis thereafter. Feed intake was determined indirectly by subtracting any leftover the following morning from the quantity offered the previous day. Feed conversion ratio, protein efficiency ratio, feed cost and feed cost per kg body weight gain were computed according to standard methods. Mortality was also recorded. Means of data collected were subjected to analysis of variance (ANOVA) (Little and Hills, 1978). Treatment means were compared using Duncan's New Multiple Range Test (DNMRT) where significant treatment effects were observed (Obi, 1990).

\section{Results and Discussion}

The gross composition of the experimental broiler starter diets are presented in table 1 . Metabolizable energy in diet T1 containing maize at $54.00 \%$ was higher (2800 $\mathrm{Kcal} / \mathrm{kg}$ ) compared to diets $\mathrm{T} 2, \mathrm{~T} 3$ and $\mathrm{T} 4$ containing $27.00 \%$ of maize and various combinations of PKC, YPM and PPM. This indicated that replacing maize in the diets reduced the energy levels; however, the crude protein levels were higher in diets containing PKC, YPM and PPM. The variations in metabolisable energy and crude protein levels in the diets resulted mainly from differences in gross composition of these nutrients in $\mathrm{PKC}$, YPM, PPM and maize (Aduku, 2004;
Anosike, 2008)

The proximate and gross energy composition (Table 2) indicated that PKC contained higher crude protein $(17.50 \%)$ and crude fibre $(17.05 \%)$ than YPM and PPM. YPM and PPM however, contained higher NFE than PKC though PKC recorded comparable gross energy. It is probable that the high gross energy value $(2455 \mathrm{kcal} / \mathrm{kg})$ of PKC might have resulted from residual oil in the cake.

Table 3 indicated the performance of starter broilers fed different combinations of PKC, YPM and PPM. Body weight gain of broilers fed diet T4 was highest (861.93g) while chicks fed diets $\mathrm{T} 3$ recorded the lowest value $(724.43 \mathrm{~g})$. However, only birds on diet T4 recorded significantly $(p<0.05)$ higher body weight gain. This might have resulted from the high crude protein level in the diet T4. It has been documented (Pesti, 2009 and Berres et al, 2010) that increased crude protein level results in increased growth, feed efficiency and carcass yields. The comparable body weight gains of broilers on diets T2 and T3 with diet T1 (control) agree somewhat, with the findings of Nworgu and Ogbosuka (2003) and Akinmutimi et al (2008) who similarly reported comparable body weight gain of broiler birds fed plantain peel and yam peel, respectively.

Similarly, feed intake was significantly $(p<0.05)$ higher $(1886.63 \mathrm{~g})$ among chicks on diet T4 and lower (1564.63g) among those on diet T1 (control). It would appear that the higher metabolisable value of diet T1 resulted in the low feed intake (Anyanwu et al, 2003 and Esonu et al, 2004). Conversely, the low metabolisable energy, high crude fibre levels as well as energy: protein ratio might have resulted in the higher feed consumption level of chicks on diets T2, T3 and T4 (Esonu, 1998 and Esonu et al, 2006). 
Table 2: Proxi mate and Gross en ergy of palm kernel cake, yam peel and plantain peel

\begin{tabular}{llll}
\hline Nutrients & Palm kernel cake & Yam peel & Plantain peel \\
\hline Dry matter & 91.02 & 88.90 & 87.58 \\
Crude protein & 17.05 & 5.09 & 5.73 \\
Ether extract & 6.90 & 4.89 & 2.06 \\
Crude fibre & 17.05 & 5.01 & 5.06 \\
Ash & 8.40 & 3.21 & 5.62 \\
NFE & 45.20 & 62.78 & 70.30 \\
Gross energy $(\mathrm{Kcal} / \mathrm{kg})$ & 2440.00 & 2455.10 & 2239.51 \\
\hline
\end{tabular}

Protein efficiency ratio (PER) was highest among broilers fed diet T1, this was however not enough to improve the body weight gain. Birds on diets T2, T3 and T4 nevertheless, recorded similar $(\mathrm{p}>0.05)$ PER. There was a significant reduction in feed cost at $50.00 \%$ replacement of maize with combinations of PKC, YPM and PPM. The reduction in feed cost is as a result of the lower cost of PKC, YPM and PPM compared to maize in the diet. This is in agreement with Etuk et al (2010) who reported a $20 \%$ reduction in feed cost when agro by products partially replaced maize in turkey diets. Feed cost per kg body weight gain similarly, was lower among birds fed combinations of PKC, YPM and PPM. Birds fed diet T4 nevertheless, recorded significantly $(p<0.05)$ lower feed cost per $\mathrm{kg}$ body weight gain than birds in other treatment groups. Lower feed cost and feed conversion ratio that is comparable with the control might be the reason for the relatively lower feed cost per $\mathrm{kg}$ body weight gain of broiler chickens fed diets with different combinations of PKC, YPM and PPM (Esonu et al, 2006). Mortality was highest among birds on diet $\mathrm{T} 4$.

The results obtained from this study indicated that combinations of PKC, YPM and PPM could successfully replace $50.00 \%$ of maize in broiler starter diet. It

Table 3: Performance of starter broiler fed different combinations of palm kernel cake (PKC), yam peel (YPM) and plantain peel (PPM).

\begin{tabular}{|c|c|c|c|c|c|}
\hline \multirow[t]{2}{*}{ Parameters } & \multicolumn{4}{|c|}{ Combination ratios of PKC, YPM and PPM } & \multirow[t]{2}{*}{ SEM } \\
\hline & $\mathrm{T} 1(0: 0: 0)$ & $\mathrm{T} 2(2: 1: 1)$ & $\mathrm{T} 3(1: 2: 1)$ & $\mathrm{T} 4(1: 1: 2)$ & \\
\hline Initial body weight $(\mathrm{g})$ & 43.16 & 43.24 & 42.87 & 43.23 & 0.17 \\
\hline Final body weight (g) & $773.30^{\mathrm{a}}$ & $776.33^{\mathrm{a}}$ & $767.30^{\mathrm{a}}$ & $905.16^{\mathrm{b}}$ & 8.15 \\
\hline Total body weight gain $(\mathrm{g})$ & $730.14^{\mathrm{a}}$ & $733.09^{\mathrm{a}}$ & $724.43^{\text {a }}$ & $861.93^{\mathrm{b}}$ & 8.15 \\
\hline Total feed intake $(\mathrm{g})$ & $1564.63^{\mathrm{a}}$ & $1750.30^{\mathrm{b}}$ & $1814.10^{\mathrm{c}}$ & $1886.63^{\mathrm{d}}$ & 11.74 \\
\hline Feed conversion ratio (FCR) & 2.14 & 2.38 & 2.50 & 2.18 & 0.13 \\
\hline Protein efficiency ratio (PER) & 1.96 & 1.78 & 1.69 & 1.93 & 0.11 \\
\hline Feed cost $(\mathrm{A} \sharp / \mathrm{kg})$ & $87.81^{\mathrm{a}}$ & $67.17^{\mathrm{b}}$ & $66.28^{\mathrm{b}}$ & $66.28^{\mathrm{b}}$ & 3.26 \\
\hline Feed cost saving $(\%)$ & $0.00^{\mathrm{a}}$ & $23.51^{\mathrm{b}}$ & $24.51^{\mathrm{c}}$ & $24.51^{\mathrm{c}}$ & 0.25 \\
\hline Feed cost $/ \mathrm{kg}$ weight gain $(\mathrm{A})$ & $187.91^{\mathrm{a}}$ & $159.86^{\mathrm{b}}$ & $165.70^{\mathrm{b}}$ & $144.49^{\mathrm{c}}$ & 4.24 \\
\hline Mortality (number) $(\%)$ & $1(4.17)$ & $2(8.33)$ & $2(8.33)$ & $4(16.66)$ & 4.23 \\
\hline
\end{tabular}

a,b,c,d Means within rows with dissimi lar superscripts are significantly $(p<0.05)$ different 
however, appears that 1:1:2 combinations of PKC, YPM and PPM resulted in better values than $2: 1: 1$ and 1:2:1 in most of the parameters measured except mortality.

\section{References}

Aduku, A. O. 2004. Animal nutrition in the tropics. Davcon Computers and Business Bureau, Samaru, Zaria. Pp. $17-18$.

Akanno, E. C. 1998. The true metabolizable energy, nitrogen corrected true metabolizable energy and true digestible protein of selected non- conventional feeding stuffs using poultry. B. Agric. Project, Michael Okpara University of Agriculture, Umudike, pp. 4- 28.

Akinmutimi, A. H. Odoemelam, V. O and. Abasiekong, S. F. 2006. Effect of replacing maize with ripe plantain and yam peels in the diet of weaner rabbits. J. Anim. Vet. Adv., 5: 737-740.

Akinmutimi, A. H. and Onen, G. E. 2008. The response of broiler finisher birds fed graded levels of yam peel meal in place of maize-based diets. Int. J. Poult. Sci. 7(5):474-479.

Anosike, C. A. 2008. Effect of different combinations of yam peels, plantain peels and palm kernel cake in finisher broiler diets. B. Agric. Tech. Thesis. Federal University of Technology, Owerri.

Anyanwu, G. A., Esonu, B. O., Iwuala, E., Okorie, K. and Etuk, E. B. 2003. Bambara groundnut (Voandzea suberranea (L) thours) offal as partial substitute for maize in broiler diets. Trop. Anim. Prod. Res. Invest. 6: 55 61.

AOAC 1995. Official methods of chemical analysis. Association of analytical chemists. Washington DC.

Berres, J. Vieira, S. L., Dozier III, W. A.,
Cortes, M. E. M., deBarros, R., Nogueira, E. T. and Kutschenko, $M$. 2010. Broiler responses to reduced protein diets supplemented with valine, isoleucine, glycine and glutamic acid. J. Appl. Poult. Res. 19: $68-79$.

Eka, O.U. 1985. The chemical composition of yam tubers. In: Advances in yam research: The biochemistry and technology of yam tubers. Osuji, G. (Ed.) Biochemistry Society of Nigeria in collaboration with Anambra State University of Technology (ASUTECH), Enugu. P. 51-75.

Esonu, B. O. 1998. Performance and internal organ characteristics of weaned rabbits fed graded levels of dietary soybean hulls. J. Tech. Edu. Nig. (JOTEN) 3(1): 28-33.

Esonu, B. O., Azubuike, J. C., Emenalom, O. O., Etuk, E. B., Okoli, I. C., Ukwu, H. and Nneji, C. S. 2004. Effect of enzyme supplementation on the performance of broiler finishers fed Microdesmis puberula leaf meal. Int.J. Poult. Sci.3(2): 112 -114.

Esonu, B. O., Izukanne, R., Emenalom, O. O., Etuk, E. B., Inyang, O. A., Samuel, S., Ezeoke, F. and Mere, B. 2006. Evaluation and economics of enzyme supplementation on performance of broiler finishers fed soybean hull based diet. Nig. J. Anim. Prod. 33(2): 216-221.

Esonu, B. O., Ogbonna, U. D., Anyanwu, G. A., Emenalom, O. O., Uchegbu, M. C., Etuk, E. B. and Udedibie, A. B. I. 2006. Evaluation of performance, organ characteristics and economic analysis of broiler finisher fed dried rumen digesta. Int. J. Poultry Sci. 5(12):1116-1118.

Etuk, E. B., Umeobi, C. Azodo, L. N., Obasi, I. U. and Emenalom, O. O. 
2010. Utilization of low cost agro-by products in turkey diets. In: Commercialisation of livestock agriculture in Africa: Challenges and opportunities. Book of Abstracts $5^{\text {th }}$ All Afr. Conf. Anim. Agric. and $18^{\text {th }}$ Ann. Meeting of Ethiopian. Soc. Anim. Prod. (ESAP). October 25 - 28. Addis Ababa.p. 125

Ezieshi, E. V., Okhuevbie, I. F., Ezennabike, C. C. and Olomu, J. M. 2004. Comparative performance of broiler chicks fed graded levels of palm kernel cake and maize offal. Proc. $29^{\text {th }}$ Ann. Conf. Nig. Soc. Anim. Prod. Eds. H.M. Tukur, W. A. Hassan, S. A. Maigandi, J. K. Ipinjolu, A. I. Daneji. K. M. Baba and B. R. Olorede. March $21^{\text {st }}-25^{\text {th }}$, Usman Danfodiyo University, Sokoto. Pp.253 - 256.

Little, T. M. and Hills, F. J. 1978. Agricultural Experimentation-Design and Analysis. John Wiley and Sons, New York.

Nworgu, F. C. and Ogbosuka, G. E. 2003.
Ripe plantain (Musa paradisiaca) peels meal as an alternative energy source for weaned rabbits. Proc. $28^{\text {th }}$ Ann. Conf. Nig. Soc. Anim. Prod. Eds. Taiwo, A. A., Raji, A. M., Ogbonna, J. U. and Adebowale, E. A. March $16^{\text {th }}$ $20^{\text {th }}$, IAR\&T, Ibadan. Pp. 348-351.

Obi, I. U. 1990. Statistical methods of detecting differences between treatment means. Snaap Press, Enugu.

Oredein, A. O., Omole, A. J. and Ogunleke, F. O. 2003. Performance characteristics of growing snails $(A$. marginata) fed different agro by products. Proc. $28^{\text {th }}$ Ann. Conf. Nig. Soc. Anim. Prod. Eds. Taiwo, A. A., Raji, A. M., Ogbonna, J. U. and Adebowale, E. A. March $16^{\text {th }}-20^{\text {th }}$, IAR\&T, Ibadan. pp $352-354$.

Pesti, G. M. 2009. Impact of dietary amino acid and crude protein levels in broiler feeds on biological performance. $J$. Appl. Poult. Res. 18:477-486.

Received: $5^{\text {th }}$ March, 2011 Accepted: $15^{\text {th }}$ Decem ber, 2012 